\title{
Environmental compatibility of renewable energy plants
}

\author{
E. Brizio \& G. Genon \\ Turin Polytechnic, Italy
}

\begin{abstract}
In Italy and many European countries energy production from biomass is encouraged by strong economic subsidies so that biomass energy plants are getting large diffusion. Nevertheless, it is necessary to define the environmental compatibility as well as technological and economic issues dealing with the emerging renewable energy scenario. This evaluation should take into account global parameters as well as environmental impacts at regional and local scale coming from new polluting emissions. The environmental balances regarding new energy plants are of primary importance within very polluted areas such as Northern Italy where air quality limits are systematically exceeded, in particular for $\mathrm{PM}_{10}, \mathrm{NO}_{2}$ and ozone. The paper analyses the energetic and environmental performances of renewable energy plants and compares them with traditional fossil fuel energy plants. The study is focused on the anaerobic co-digestion of manure and energy crops and the combustion of poultry manure, with reference to ammonia, $\mathrm{CH}_{4}$ and $\mathrm{N}_{2} \mathrm{O}$ releases, as well as $\mathrm{NOx}$ from the energetic section. The most important conclusion that can be drawn is that the production of renewable energy from anaerobic digestion, can strongly increase ammonia and NOx emissions and, in some cases, also GHG emissions could be worrying, whereas the application of best available techniques to waste gas cleaning and energy recovery allows positive emissive balances.
\end{abstract}

Keywords: anaerobic digestion, NOx, ammonia, environmental balances, energy efficiency, biomass.

\section{Introduction}

Renewable energy plants (based on biogas produced by anaerobic digestion of manure and energy crops, vegetable oil burned by diesel engines, wood and solid 
biomass) are getting large diffusion in Northern Italy because of the benefits deriving from the production of energy on one's own, the reduction of odour nuisance from manure and the increase of its biological stability and, most of all, the economic return (pay-back times can be as short as 4-5 years in Italy) based on electricity production. The new energy scenario has to be considered within the environmental background of the area where it is introduced, involving air quality limits compliance, the use of best available techniques, energetic efficiency (also thermal), emissive balances, global warming issues, biomass origins, aspects dealing with the use of water and fertilizers for energy crops, nitrates leaching towards groundwater. These are the focus of the present study.

\section{Environmental conditions of Northern Italy}

Air quality of Northern Italy is one of the most polluted of the world, maybe the worst in Europe, due to the strong human activities and the orography of its territory. $\mathrm{PM}_{10}, \mathrm{NO}_{2}$ and ozone concentrations measured at the ground level diffusely and permanently go beyond the quality standards. In particular, $\mathrm{PM}_{10}$ concentration is only partly due to particulate primary emissions because the chemical analysis of PM measured in Northern Italy confirm that secondary particles (deriving from NOx, $\mathrm{SOx}, \mathrm{NH}_{3}$ and $\mathrm{VOC}$ ) account for $60-70 \%$ of total PM concentration (see Giugliano and Lonati [1] and CNEIA [2]). Moreover, some European studies report (De Leeuw [3]) the following aerosol formation factors, to be considered by weight, starting from gaseous pollutants: NOx 0,88 ; $\mathrm{SOx} 0,54 ; \mathrm{NH}_{3} 0,64$. As it is clear from the reported figures, in order to control and improve air quality in Northern Italy, the emissions of gaseous compounds such as NOx and ammonia (mostly emitted by agriculture) should be mainly reduced. Another strong environmental critical issue of Northern Italy is nitrate contamination of surface and ground-water resources mainly due to the use of fertilizers and the land-spreading of animal manures.

\section{Energetic and environmental performances of renewable energy plants}

As far as specific emissions of NOx are concerned, Figure 1 reports the comparison between the most frequent renewable energy technologies (the four at the top of the plot) and some fossil fuel energy plants (Natural Gas (NG) turbines and engines). As one can easily observe, renewable energy plants, unless they are equipped with efficient abatement devices, generally cause higher NOx emissions, twice, three times, up to a hundred times traditional energy plants burning natural gas, the most common fuel for new settlements in Italy. Similar remarks could be done for PM emissions from solid biomass combustion and VOC due to biogas or vegetable oil burned by engines. In spite of their impacting potential, renewable energy plants in Italy undergo very fast authorizing procedures (they are defined as public utility, not post-ponable and urgent); moreover, technical and emissive limits imposed by Italian law are not 


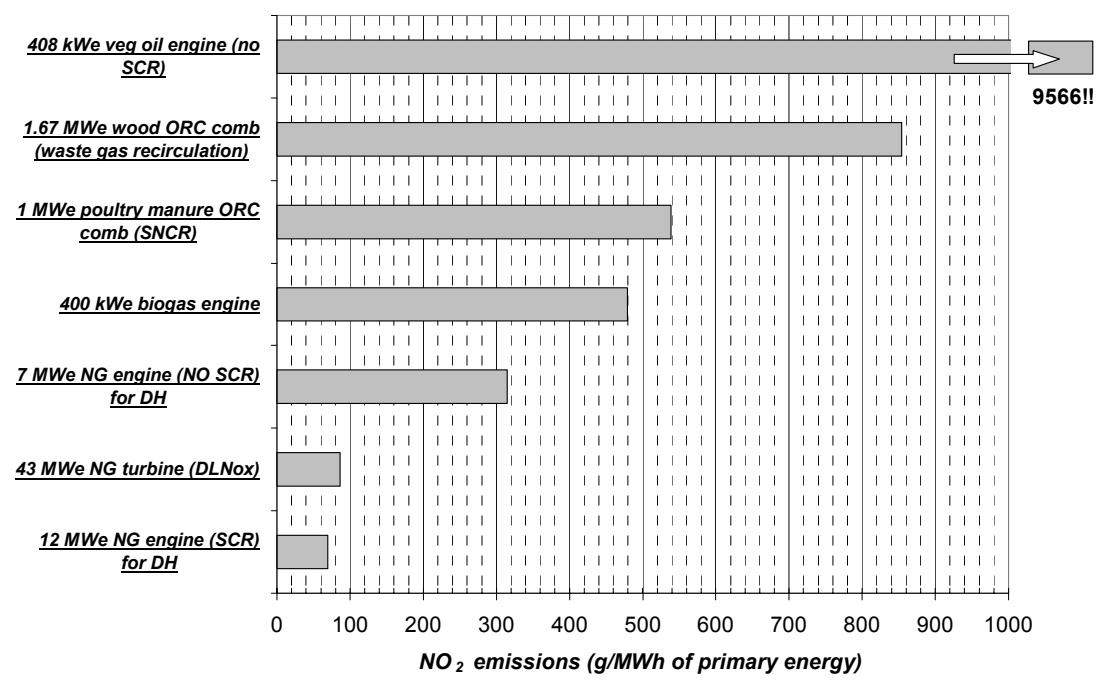

Figure 1: $\quad \mathrm{NO}_{2}$ emissions for fossil and renewable energy plants.

suitable to the possible effects, that is it is very difficult to impose abatement systems (catalytic oxidation, SCR, SNCR, air/fuel staging, etc.) that could mitigate the impacts.

Moreover, it is important to remember that emissions from renewable energy plants could be counterbalanced by the so-called avoided emissions relating to displaced existing releases; within this context, the recovery of thermal energy plays a crucial role (the potential thermal recovery for an engine is around $40 \%$, for a wood combustor even larger than 60\%). Unfortunately, cogeneration is often disregarded because the aspect that does really matter in economic terms is electricity and so large quantities of thermal energy is dispersed and the emissive balance could become strongly negative at the local scale.

In the next chapter two case studies are reported, the first one dealing with biogas-to-energy obtained from the anaerobic digestion of manure and energy crops, the second one relating to the combustion of poultry manure alone.

\section{Environmental compatibility for anaerobic digestion plants}

The main environmental concerns referring to animal manure management are odours due to uncontrolled fermentation, ammonia emissions from the storage and the land-spreading and greenhouse gases (GHG) release $\left(\mathrm{CH}_{4}\right.$ and $\left.\mathrm{N}_{2} \mathrm{O}\right)$. Anaerobic digestion (AD) can be an answer to odour nuisance but it is totally ineffective on nitrogen content of digested materials; moreover, as we will see later on, also $\mathrm{CH}_{4}$ and $\mathrm{N}_{2} \mathrm{O}$ could be enhanced with respect to the ante operam conditions.

Due to obvious economic drivers, manure is rarely digested alone; on the contrary, energy crops such as maize, triticale and sorghum and, sometimes, 
agro-residues are fed to digesters in order to increase the volatile solid (VS) content and then biogas production (higher methane yields). AD plants formally proposed in Northern Italy in the last months are several and they are all characterised by high crop/manure ratios within the mixture to be digested, (crops sometimes represent more than $50 \%$ of the foodstock).

As previously mentioned, within anaerobic digesters, nitrogen contained in the primary mixture is not removed and almost the same amount can be found in the digested material, under different forms: as a matter of fact, a large part of nitrogen contained in proteins is hydrolyzed to ammonium ion $\left(\mathrm{NH}_{4}+\right)$ and dissolved ammonia $\left(\mathrm{NH}_{3}\right)$ that can be volatilized; an increase in $\mathrm{pH}, \mathrm{NH}_{3}$ concentration and temperature, 3 conditions that do occur after anaerobic digestion, enhance ammonia emissions during storage and after field application. Moreover, nitrogen content of the mixture to be digested is strongly increased by the use of energy crops (for example, maize silage contain $4.3 \mathrm{~kg} \mathrm{~N} /$ ton of FM).

This way, the nitrogen amount to be managed along with digested materials can be strongly larger than that in primary manure and it is surely more suitable for volatilization.

Based on reliable emission factors and international studies (CORINAIR, IPCC and IPPC BAT reference documents, Italian experimental results and so on) it is possible to assess that $34 \pm 11 \%$ of nitrogen contained in the storage is emitted as $\mathrm{NH}_{3}-\mathrm{N}$ from the storage and land-spreading (almost 15\% from the land-spreading) of fresh animal manure.

As already described, the considered ammonia emissions can be enhanced by anaerobic digestion: Clemens et al. [4] describes that, during the summer, ammonia emissions from the storage of digested cattle slurry are twice the releases from untreated manure $\left(222,5 \mathrm{~g} \mathrm{NH}_{3} / \mathrm{m}^{3}\right.$ slurry vs. $110,5 \mathrm{~g} \mathrm{NH}_{3} / \mathrm{m}^{3}$ slurry). Balsari [5] reports an increase of $12,5 \%$ due to anaerobic digestion of manure whereas CRPA [6] describe that the increase can be up to $73 \%$.

Figure 2 reports the emission of ammonia and NOx from the storage and land-spreading of digested manure and energy crop (maize) on the basis of the described average emission factors, without considering the chemical-physical conditions induced by digestion (that could still enhance the emissions, as previously explained); as a matter of fact, according to different crop/manure ratios, ammonia emissions can be much larger than those from fresh manure (scenario 0), up to three times when manure represents just one third of the mixture to be digested.

As far as energetic scenarios at the regional scale are concerned, in the case we decide to send $10 \%$ of manure produced in the Piedmont region $(1300 \mathrm{kt} / \mathrm{y})$ to $\mathrm{AD}$ together with the same amount of energy crop (maize), $531 \mathrm{GWh}_{\mathrm{el}}$ could be produced but ammonia emissions would show an increase of around $2300 \mathrm{t} / \mathrm{y}$ and more than $700 \mathrm{t} \mathrm{NOx} / \mathrm{y}$ would be emitted, that corresponds to a huge neoformation potential of more then $2000 \mathrm{t} / \mathrm{y}$ of $\mathrm{PM}_{10}$ (or, more correctly, $\mathrm{PM}_{2.5}$ ). These data can be also seen as a specific emission of secondary particulates around $4 \mathrm{~g} / \mathrm{kWh}_{\mathrm{el}}$ due to energy production from $\mathrm{AD}$, whereas the average secondary $\mathrm{PM}$ emission factor for the Italian national power system $\left(\mathrm{SO}_{2}: 0,67\right.$ 


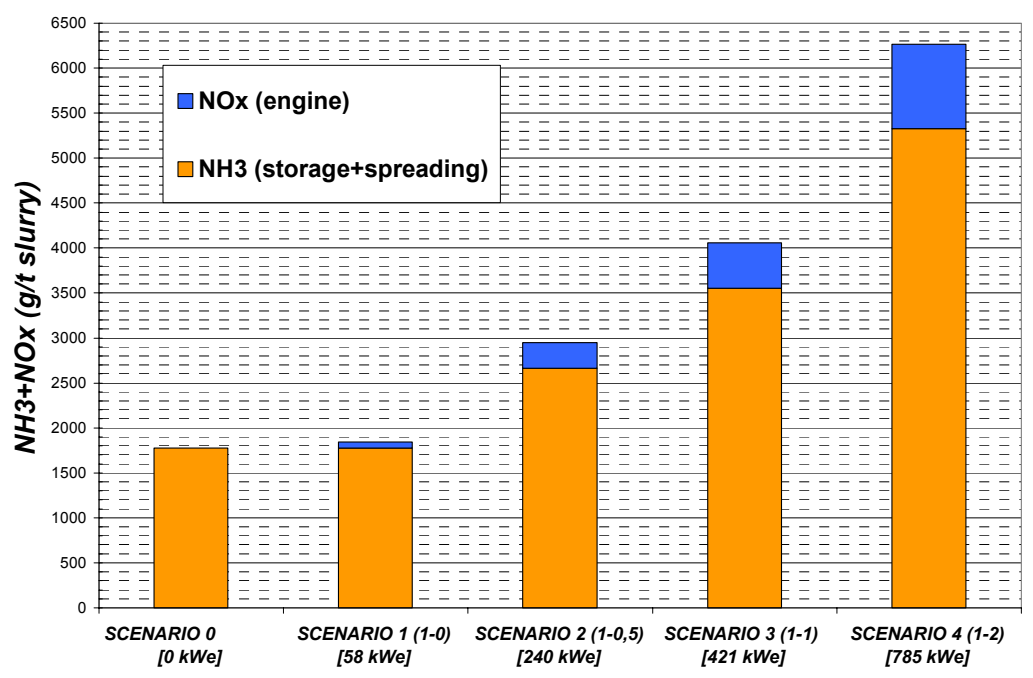

Figure 2: Ammonia and NOx emissions due to AD; in brackets $\mathrm{t}$ manure $/ \mathrm{h}-$ $\mathrm{t}$ maize/ $\mathrm{h}$ fed to digesters.

$\mathrm{g} / \mathrm{kWh}_{\mathrm{el}}$; NOx: 0,523 g/kWh $\mathrm{e}_{\mathrm{el}}$; PM: $\left.0,024 \mathrm{~g} / \mathrm{kWh}_{\mathrm{el}}\right)$ is $0,85 \mathrm{~g} / \mathrm{kWh} \mathrm{el}_{\mathrm{el}}$. As obvious, the reported figures refer to plants without any ammonia abatement devices, that are not generally planned for new installations. The large amount of ammonia release could be strongly reduced by employing stripping-absorbing towers for digested materials $\left(\mathrm{H}_{2} \mathrm{SO}_{4}\right.$ solutions are usually applied as absorbents in order to obtain a fertilising by-product that could be sold); alternatively, the storage tank could be covered (a solid cover should be implemented because straw covers or natural crusts could be less effective in reducing $\mathrm{NH}_{3}$ emissions and have the potential to increase GHG emissions, as reported by Amon et al. [7]) and Best Available Techniques to the land spreading of digestates (immediate incorporation, use of deep injectors) should be applied. On the other hand, NOx emissions could be largely reduced by Selective Catalytic Reduction (up to $90 \%$ ), but the technical feasibility of this solution depends on the poisoning potential of waste gas and the purification possibilities.

As far as greenhouse gases balances are concerned, 0,0032 $\pm 0,0012 \mathrm{~kg} \mathrm{~N} \mathrm{~N}_{2} \mathrm{O}$ $\mathrm{N} / \mathrm{kg}$ excreted $\mathrm{N}$ are expected to be emitted from the storage of fresh manure; moreover, an indirect $\mathrm{N}_{2} \mathrm{O}$ should be considered, dealing with volatilised nitrogen: the proposed emission factor is $0.01 \mathrm{~kg} \mathrm{~N} \mathrm{~N}_{2} \mathrm{O}-\mathrm{N} /(\mathrm{kg} \mathrm{NH}-\mathrm{N}+\mathrm{NOx}-\mathrm{N}$ volatilised). We do not have experimental information about the effect of increased nitrogen content due to co-digestion of manure and energy crops but, according to the approach followed by international emission factors $\left(\mathrm{N}_{2} \mathrm{O}\right.$ releases are likely to be proportional to nitrogen content), a further emissive increase for $\mathrm{N}_{2} \mathrm{O}$ could be expected in this case.

Another environmental aspect that should be analysed when dealing with anaerobic digestion is the post-methanation potential, that is the uncontrolled 
emission of methane from the storage of digested materials. As a matter of fact, the post-methanation somehow depends on the volatile solid content of the slurry and it is well known that the VS removal efficiency of AD is never $100 \%$; on the contrary VS conversion to biogas is for the most part a function of the biodegradability of the primary mixture to be digested and the dimension of the digester through the hydraulic retention time (HRT). Based on several experimental data, the VS removal efficiency is often lower than $50 \%$.

This way, taking into account the VS content in the digested material that sometimes can be remarkable (more than $50 \%$ of the original quantity) on the one hand, given the temperature of digested materials, the presence of specialized anaerobic biomass coming from the digesters and the long time at disposal for the storage (even more than 100 days) on the other hand, the postmethanation could represent a considerable emission.

Some authors (Weiland [8]) report that "typically 5-15\% of the total biogas produced can be obtained from post-methanation of residues" while the CROPGEN project [9] inform that up to $12-31 \%$ of total methane production can be recovered from post-methanation of digestates. The post-methanation potentials measured within the CROPGEN project for digestates incubated for 100 days at 5,20 and $35^{\circ} \mathrm{C}$ were $1-9,73-120,133-1971 \mathrm{CH}_{4} / \mathrm{kg}$ VS respectively. As far as the mentioned project is concerned, the post-methanation potential does not change during feeding regimes with $30-40 \%$ of crops in the foodstock. Other studies (Kaparaju [10]) report post-methanation potentials of 160-210 at 35$55^{\circ} \mathrm{C}, 53-87$ at $15-20{ }^{\circ} \mathrm{C}$ and $261 \mathrm{CH}_{4} / \mathrm{kg} \mathrm{VS}$ at $10^{\circ} \mathrm{C}$ for a storage of 250 days.

In order to develop proper GHG balances around the technical choice of anaerobically digesting manure and crops, a post-methanation potential of 501 $\mathrm{CH}_{4} / \mathrm{kg}$ VS and a VS removal efficiency of $50 \%$ can be used to calculate the indirect $\mathrm{GHG}$ emissions from the storage of digested materials. As far as GHG emissions from untreated manure are concerned, the emission factors proposed by IPCC can be considered a good reference: for a mixture of swine and dairy cattle manure and a climate between cool and temperate, an emission of around $4 \mathrm{~kg} \mathrm{CH}_{4} / \mathrm{t}$ of manure can be expected.

Figure 3 reports the GHG emissions for 5 different scenarios, from traditional manure management (storage and spreading, scenario 0) to anaerobic digestion of different mixtures of manure and maize (scenario 1 to 4 ). The figures point out that $\mathrm{AD}$ of manure alone involves a strong reduction of methane emissions from the storage with respect to scenario 0 . On the other hand, co-digestion of manure and energy crops (when energy crops represent from 30 to $70 \%$ of foodstock), causes indirect GHG emissions that nullify the "energy bonus" due to $\mathrm{CO}_{2}$ avoided emissions; in other words, in the case the energy bonus, that is strongly economically propelled, is cancelled by uncontrolled released, the renewable energy mission of $\mathrm{AD}$ would be betrayed. Furthermore, it should be said that the proposed balances neglect the emissions of $\mathrm{CH}_{4}$ and $\mathrm{N}_{2} \mathrm{O}$ from the biogas engine, as well as methane releases from digesters and pressure valves and $\mathrm{CO}_{2}$ eq emissions relating to cultivation and transport of energy crops; these 


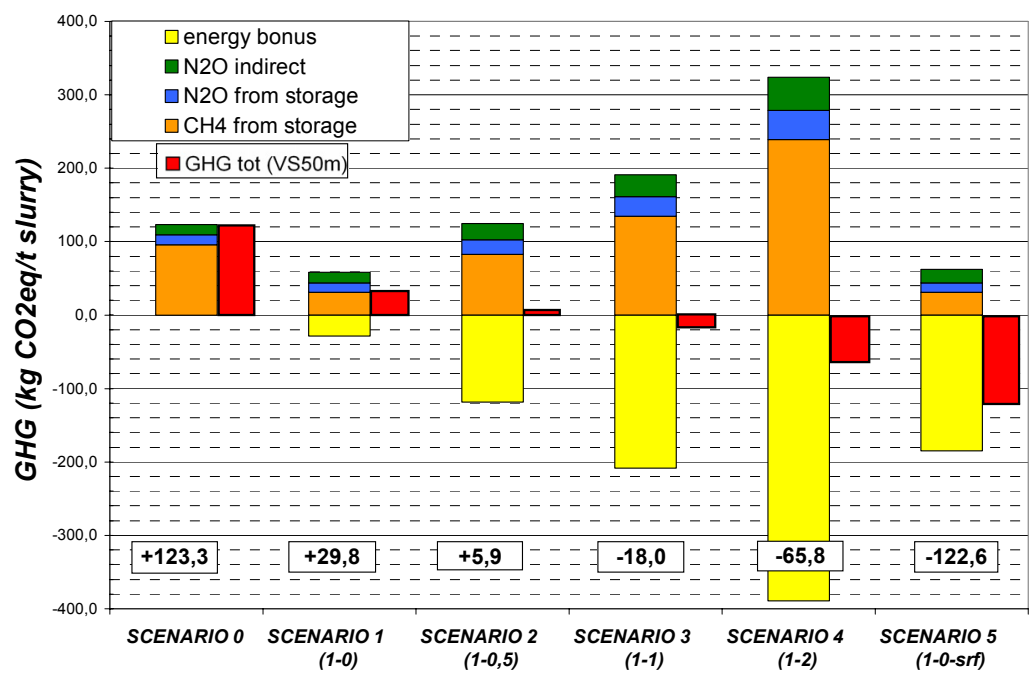

Figure 3: GHG balance. SCENARIO 0: manure as usual (storage+land spreading); SCENARIO 1-4 (anaerobic digestion of manure and maize): in brackets $\mathrm{t}$ manure $/ \mathrm{h}-\mathrm{t}$ maize $/ \mathrm{h}$ fed to digesters; SCENARIO 5: anaerobic digestion of manure alone $(1 \mathrm{t} / \mathrm{h})$ and combustion of poplar wood from SRF cultivated instead of maize in the same area required by scenario 3 (1 t of maize/h).

contributions would even worsen the reported GHG balances. Nevertheless, based on our assumption the indirect emissions of GHG can be quantified as 400 $\pm 67 \mathrm{~g} \mathrm{CO}_{2} \mathrm{eq} / \mathrm{kWh}_{\mathrm{el}}$, mainly due to $\mathrm{CH}_{4}$ releases from the storage of digestate, that is comparable to the Italian average $\mathrm{CO}_{2}$ emission factor for energy production (496 $\mathrm{g} \mathrm{CO}_{2} / \mathrm{kWh}_{\mathrm{el}}$ ): the reported figure represent the average value for three different post-methanation models.

In order to compare biogas energy production to other renewable sources, scenario 5 presented by Figure 3 reports the balance referring to $\mathrm{AD}$ of manure alone (as in scenario 1) summed to energy production from the combustion of poplar wood (from short rotation forestry) cultivated in the same area required by the production of maize in the case of scenario $3(1 \mathrm{t} / \mathrm{h})$. The GHG balance for scenario 5 turns out to be largely better than the analysed anaerobic co-digestion hypotheses; moreover, we did not consider that poplar cultivation requires much fewer fertilizers, water and care than maize, so that lower $\mathrm{CO}_{2}$ indirect emissions would increase the positivity of the balance in favour of wood combustion.

The negative impacts of indirect emissions from co-digestion of manure and energy crop are confirmed by some recent studies ([11] and [12]); the first presentation points out a range from 250 to $600 \mathrm{~g} \mathrm{CO}_{2} \mathrm{eq} / \mathrm{kWh}_{\mathrm{el}}$ for $\mathrm{AD}$ (the higher value corresponds to co-digestion of manure and energy crops and it is mainly due to production and transport of biomass), while the second author reports (personal communication) that "in extreme cases (open storage of digestate and low HRT) the $\mathrm{CO}_{2}$ eq balance can reach levels of 600-700 $\mathrm{g}$ 
$\mathrm{CO}_{2} \mathrm{eq} / \mathrm{kWh}$ el that means: biogas production causes the same GHG emissions as German conventional electricity production". It should be remembered that the reported indirect emissions are much larger than the official LCA figures pointed out by EEA reports [13], that are between 80 and $148 \mathrm{~g} \mathrm{CO}_{2} \mathrm{eq} / \mathrm{kWh}_{\mathrm{el}}$.

As one can easily observe from the mentioned data, energy production from AD could have a negative meaning as far as sustainability aspects are concerned. As obvious, the solution can be technological as high HRT, thermophilic digestion regimes, gas-tight storage of digestates (and combustion of released methane in the biogas engine) and catalytic oxidation of waste gas from the engine can strongly reduce methane indirect emissions. So far, the strong economic subsidies mainly based on electricity production represent a demotivating factor for this kind of technical devices.

\section{Environmental compatibility of poultry manure combustion}

Poultry manures can be managed traditionally, as a direct fertilizer; otherwise, it can be disposed of through composting, anaerobic digestion together with liquid manures and energy crops, gasification or direct combustion in a fluidised bed or a grate firing combustor. The first solution does not produce energy, it can be costly and some problems can arise for odours and waste gas cleaning; the second option requires a strong dilution of poultry manures because its nitrogen content (up to $5 \%$ by weight) can inhibit anaerobic reactions and, most of all, $\mathrm{AD}$, if adequate technological devices are not applied, can cause strong ammonia and GHG emissions, as described in the previous chapter; the last opportunity, direct combustion, is supported by a reliable technology, it can produce combined heat and power in a efficient way (overall efficiency up to $80 \%$ ), the atmospheric emissions can be reduced and minimized by modern cleanup devices, the ash is stable, sterile, easier to handle and transport and more marketable as an organic fertiliser than conventional poultry litter. So, direct combustion seems to be the most interesting technical solution and the associated environmental aspects have been robustly investigated in a study focused on externalities assessment [14].

The combustion of poultry manure can bring about considerable "avoided emissions", due to the replacement of existing boilers in the case thermal energy is correctly recovered, the reduction of ammonia, $\mathrm{N}_{2} \mathrm{O}$ and methane releases from the storage and spreading of poultry manure and the production of electricity from a renewable fuel.In particular, ammonia emissions from the storage and spreading of poultry manure from laying hens are around $0,180 \mathrm{~kg}$ $\mathrm{NH}_{3} /$ head/y, $\mathrm{N}_{2} \mathrm{O}$ direct releases are around $0,047 \mathrm{~kg} \mathrm{~N}_{2} \mathrm{O} / \mathrm{kg}$ excreted $\mathrm{N}$, whereas methane emissions can be considered about $0,056 \mathrm{~kg} \mathrm{CH}_{4} / \mathrm{head} / \mathrm{y}$.

Table 1 reports the emissive balance for a ORC grate firing combustor burning $3500 \mathrm{~kg} / \mathrm{h}$ of poultry manure $\left(6 \mathrm{MW}_{\text {th }}\right.$ in), producing $6000 \mathrm{MWh}_{\mathrm{el}}$ and $10667 \mathrm{MWh}_{\text {th }}$ per year, equipped with: spreader stoker, waste gas recirculation, SNCR, multi-cyclone, spray-drier (lime) and fabric filters. The recovered thermal energy (coupled with a $4 \mathrm{MW}$ auxiliary natural gas boiler) is used to feed a district heating for a town of 2.500 inhabitants $\left(320.000 \mathrm{~m}^{3}\right)$. 


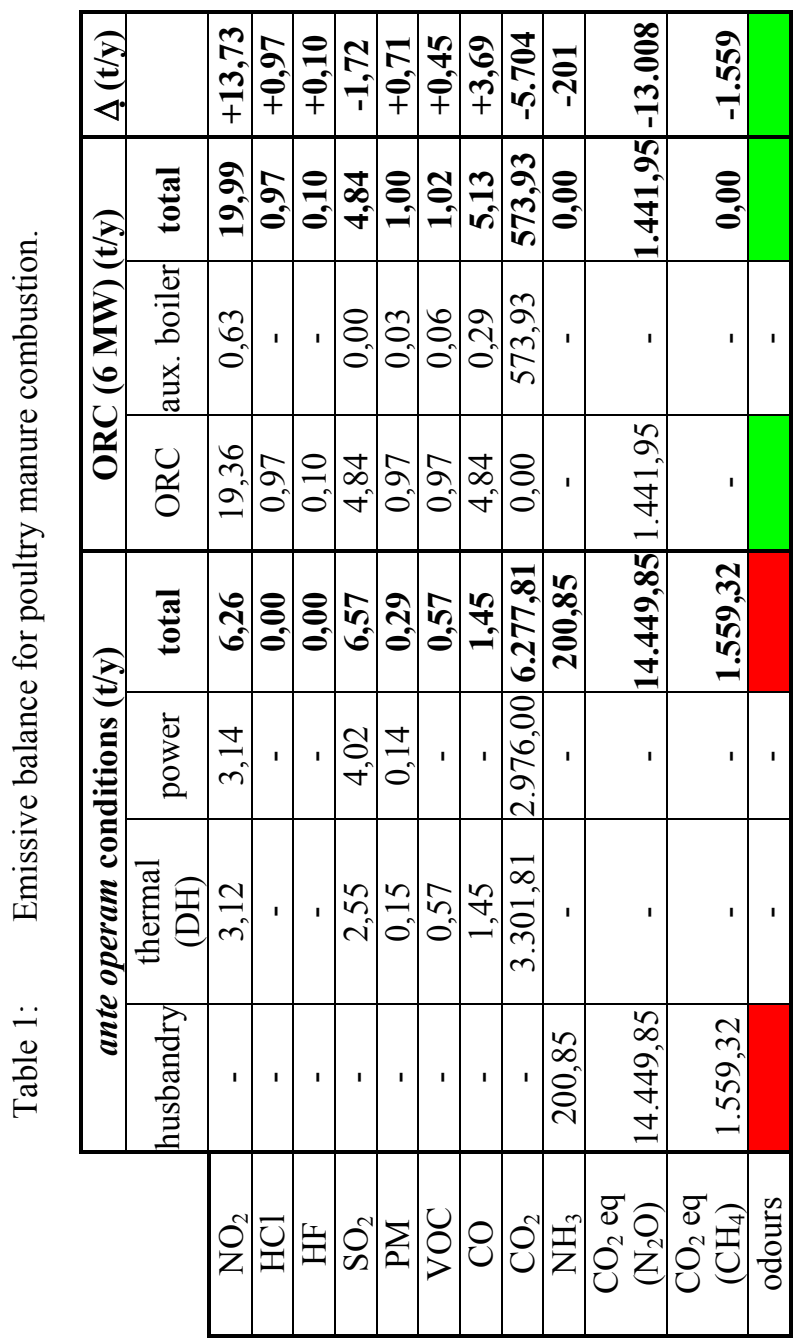


As one can easily notice, poultry manure combustion can ensure strong reductions for greenhouse gases, ammonia and odours, whereas a very small emissive increase can be expected for $\mathrm{NO}_{2}, \mathrm{PM}$ and $\mathrm{CO}$ on the local scale. The effect of the described increase on air quality at the local scale is negligible and it can be compensated by the avoided concentrations relating to the displacement of civil heating or existing boilers. Moreover, both $\mathrm{NO}_{2}$ and $\mathrm{NH}_{3}$ are precursor of $\mathrm{PM}_{2.5}$ at the regional scale (as ammonium nitrates) and then the increase of $\mathrm{NO}_{2}$ emissions is strongly counterbalanced by the reduction of ammonia releases. The ExternE methodology [15] have been applied to the analyzed plant in order to build the overall environmental balance; the external costs have been calculated on the basis of pollutant concentration at the ground level, exposed population in the studied areas, exposure-response functions and health impact monetization. The overall balance turn out to be strongly positive because of the large reduction of ammonia emissions that brings about a large environmental benefit as avoided secondary particles generation and GHG release. Moreover, we did not consider the benefit deriving from the reduction of odors and the decrease of $\mathrm{N}$ leaching towards groundwater.

\section{Conclusions}

Renewable energy plants are strongly encouraged by European legislation but their effect on air quality could be negative, in particular for compromised areas such as Northern Italy. As a matter of fact, specific emissions for NOx, PM and VOC can be larger than fossil fuel plants (in particular for NG systems) and thermal energy is often not recovered so that energetic efficiency is not maximised and existing energy plants are not substituted. Moreover, energy plants such as anaerobic digesters can involve strong increase of ammonia and indirect GHG emissions that can make unsure the environmental sustainability of the technical choice. Anyway, technical solutions that can ensure the compatibility of renewable energy plants do exist but their application is hindered by the subsidy's formulation and the technical legislation that is not suitable to manage the possible environmental impacts.

\section{References}

[1] Giugliano, M., Lonati, G., Polveri fini in atmosfera: la componente secondaria, ENERGIA 3/2005, July 2005.

[2] Commissione Nazionale Emergenza Inquinamento Atmosferico (CNEIA), Relazione conclusiva, 20 February 2006.

[3] De Leeuw, F. A set of emission indicators for longrange transboundary air pollution, Environmental Science \& Policy, n. 5, pp. 135-145, 2002.

[4] Clemens, J., Trimborn, M., Weiland, P., Amon, B., Mitigation of greenhouse gas emissions by anaerobic digestion of cattle slurry, Agriculture, Ecosystems and Environment 112 (2006) 171-177. 
[5] Balsari, P., "biogas dal comparto agro biogas dal comparto agrozootecnico: zootecnico: l'esperienza europea esperienza europea" Workshop internazionale digestione anaerobica: la situazione italiana.

[6] Immovilli, A., Fabbri, C., Valli, L., Odour and ammonia emissions from cattle slurry treated with anaerobic digestion, Centro Ricerche Produzioni Animali, from the web.

[7] Amon, B., Kryvoruchko, V. Amon, T., Influence of different methods of covering slurry stores on greenhouse gas and ammonia emissions, International Congress Series 1293 (2006) 315-318.

[8] Weiland, P., Production and energetic use of biogas from energy crops and wastes in Germany, Appl. Biochem. Biotechnol. 109: 263-274, 2003.

[9] Renewable energy from crops and agrowastes, CROPGEN Project, D17: Database on the methane production potential from mixed digestion.

[10] Kaparaju, P.L.N., Rintala, J.A., Effects of temperature on postmethanation of digested dairy cow manure in a farm-scale biogas production system. Env. Technol. 24 (2003): 1315-1321.

[11] Balsari, P., Panoramica europea ed esperienze regionali, Convegno BIOGAS E RECUPERO ENERGETICO: tra il presente e il futuro. 1-2 Aprile 2009.

[12] Gronauer, A., Comparison of different technologies: the road to success, Conference Anaerobic Digestion: opportunities for agriculture and environment. Regione Lombardia, from the web.

[13] EEA Technical report No 10/2008. Maximising the environmental benefits of Europe's bioenergy potential.

[14] Brizio, E., Genon, G. Environmental compatibility of energy production from biomass at global, regional and local scale, CEMEPE 2009.

[15] Bickel, P. Friedrich, R., ExternE, externalities of energy. Methodology 2005 update. European Commission, DG XII. 